\title{
The Effectiveness of Learning Model SQ4R on Learning Outcomes Indonesian Subject of Students in Elementary School
}

\author{
Naeklan Simbolon ${ }^{1 *}$, Eva Betty Simanjuntak ${ }^{2}$, Nasriah $^{3}$, Ivana Rose Ginting ${ }^{4}$ \\ $\{*$ naeklan@unimed.ac.id \} \\ Faculty of Education, Univesitas Negeri Medan, Indonesia ${ }^{1}$
}

\begin{abstract}
This study aims to examine the effect of SQ4R model implementation on the learning outcomes of Indonesian in elementary students. The type of this research is Quasi Eksperimen. Sample of this research consist of 60 students. Sampling technique in this research is by purposive sampling technique taking subject not based on random sampling. or area but based on the existence of certain purpose, that is with class of VA as experiment class and VB as a control class. Before the research done, the researchers tested the validity and reliability. Based on data analysis, the research results obtained as follows: average pretest of students in the experimental class before being treated by using SQ4R model of 43.3 and control class obtained the average score of pre-test students of 55.2. And the result of study of experiment class student after being treated by using SQ4R model equal to 74,2 and in control class obtained average value 63,7 . Thus there is a significant influence on the application of SQ4R learning model to the learning outcomes of Indonesian Primary School Students. Based on the results of research can be concluded that there is influence of SQ4R model on learning outcomes Indonesian.
\end{abstract}

Keywords: Learning model, SQ4R, indonesian subject, learning outcomes

\section{Introduction}

Education is an effort of every nation and state to pass on knowledge from generation to generation. The education is also expected to create high quality and competitive learners to face the competition in the globalization era today. Improving the quality of human resources is one of the emphasis of educational goals. The success of the national education system is strongly influenced by the teaching process that the teacher provides. Therefore, teachers as educators should be able to create an atmosphere of learning that can help improve the quality of education peoses itself.

Indonesian as a communication tool of Indonesian society that has a role to lead and deliver knowledge to various circles and level of education. All levels of education in delivery, of course using the Indonesian language as the introduction. Therefore, the Indonesian language clearly has an important role as a material science and technology in its dissemination to the world of education.

In accordance with the position of Bahasa Indonesia as the national language and the language of the country. So, the function of Indonesian language and literature subjects are: (1) means of fostering unity and unity of the nation (2) means of improving knowledge and 
skills of Indonesian language in order to preserve and develop culture (3) means of increasing knowledge and skills of Indonesian language to reach and develop science Knowledge, skills and art (4) means of disseminating the use of good Indonesian bebah for the purposes of various problems, and (5) means of developing reasoning.

The scope of Indonesian language and literature subjects covers language mastery, ability to understand, appreciate literature, and the ability to use the Indonesian. Indonesian learning is directed to improve students' ability to communicate in good and correct Indonesian, either orally or in writing. In learning Indonesian in primary school there are four aspects of language skills that include listening, speaking, reading and writing skills. The four aspects of language skills are related to one another.

Based on the results of observations and interviews of researchers to teachers of primary school in Medan is known that the value of student learning outcomes is low and has not reached the Indonesian KKM is 70 . Teachers use less variation in the process of learning Indonesian, in other words teachers tend to use conventional methods in which teachercentered learning activities, so that students are less active in the learning process where students are less able to express their opinions.

One of the fundamental things that teachers need to understand is how to understand the position of the learning model as one of the components for the success of learning activities. Teachers need to determine the appropriate model of learning so that the material can be easily understood learning students, teachers are obliged to implement improvements in learning.

The SQ4R model (survey, question, read, reflect, recite, and review) is one of the techniques of reading to understand the content of the reading that uses the steps systematically in its implementation. In using this model of course, a reader needs to determine in advance the purpose of reading. In addition, readers also need to determine the focus information they need. Where in this model, students are directed to scrutinize, create questions, read texts, review, and provide examples in the actual context. With this learning model is expected to learn Indonesian student learning can be increased.

The learning process is a very important element in the process of education in schools. A person's view of learning affects his or her learning-related actions and everyone has a different view of learning. By learning human beings will be able to change itself towards the better in terms of knowledge, skills, and attitude. Psychologically, learning is a process of change that changes behavior as a result of interaction with the environment in meeting their needs, the changes will be evident throughout aspects of behavior.

[1] says that learning is a process of behavior change to achieve a wide range of knowledge, skills and attitudes. Learning is a process of interaction between stimulus and response. Learning is considered as a process of behavior change as a result of the experience and practice Learning is a process of behavior change due to experience and practice. The objective of the study is the change in behavior, both concerning the knowledge, skills, attitudes [2]. According to [3] Learning is defined as a persisting change in human performance or performance potential, learning comes about as a consequence of, the learner's experience and interaction with the world. Based on the above quote, learning is defined as the last change in human performance or potential performance, learning emerged as a consequence of the student experience and interaction with the environment.

Learning is a process attempts someone who aims to obtain a change in behavior or overall appearance both concerning the knowledge, skills, attitudes with a series of learning activities for example by reading, watching, listening, etc. It can be concluded that learning can not be separated from human life. Where learning is a process of interaction with the environment. Learning can also be interpreted as the individual events, the events of the 
occurrence of a change in behavior as a result of the experience. Learning would be better if the subject learning experience or do it yourself through a variety of events and activities they do.

It's basically what the results obtained from an activity, while learning is a process that resulted in a change in individuals, the changes in behavior, both aspects of the knowledge, skills and attitude aspects.

The learning result is a term used to indicate the level of success achieved by a person after certain business. In this case the learning outcomes achieved by students in a particular field of study after participating in the learning process. In the process of obtaining a good result it is necessary to learn appropriate learning methods means that in accordance with the conditions and circumstances of everyday life are contextual, so what is the result of learning can be met with a number of measurements of learning outcomes that meet the standards.

According to [4] learning is generally interpreted as a change in individuals that occur through experience, and not because of the growth or development of the body or characteristics of a person from birth". Meanwhile, according to [5] learning is a business or activity that aims to make changes within a person include changes in behavior, attitudes, habits, science, skills, and so on.

Meanwhile, according to [6] learning is a process of business undertaken by a person to gain a new change of behavior as a whole, as a result of his own experience in interaction with the environment. From some of the expert opinions above can be understood that the changes include the goals that want to be generated from the learning process as a result of business or activities in the form of experience in interaction with the environment.

This is reinforced by the opinion of [7] learning is a change of behavior or appearance, with a series of activities. For example, by reading, observing, listening, imitating, and so on. Based on the opinions of the experts above, it can be defined that learning is an activity aimed at generating behavioral changes based on individual experience in interaction with the environment, which involves cognitive, affective, and psychomotor aspects. Education is an effort of every nation and state to pass on knowledge from generation to generation. The education is also expected to create high quality and competitive learners to face the competition in the globalization era today. Improving the quality of human resources is one of the emphasis of educational goals. The success of the national education system is strongly influenced by the teaching process that the teacher provides. Therefore, teachers as educators should be able to create an atmosphere of learning that can help improve the quality of education peoses itself.

Indonesian as a communication tool of Indonesian society that has a role to lead and deliver knowledge to various circles and level of education. All levels of education in delivery, of course using the Indonesian language as the introduction. Therefore, the Indonesian language clearly has an important role as a material science and technology in its dissemination to the world of education.

In accordance with the position of Bahasa Indonesia as the national language and the language of the country. So, the function of Indonesian language and literature subjects are: (1) means of fostering unity and unity of the nation (2) means of improving knowledge and skills of Indonesian language in order to preserve and develop culture (3) means of increasing knowledge and skills of Indonesian language to reach and develop science Knowledge, skills and art (4) means of disseminating the use of good Indonesian bebah for the purposes of various problems, and (5) means of developing reasoning.

The scope of Indonesian language and literature subjects covers language mastery, ability to understand, appreciate literature, and the ability to use the Indonesian. Indonesian learning 
is directed to improve students' ability to communicate in good and correct Indonesian, either orally or in writing. In learning Indonesian in primary school there are four aspects of language skills that include listening, speaking, reading and writing skills. The four aspects of language skills are related to one another.

Based on the results of observations and interviews of researchers to teachers of primary school in Medan is known that the value of student learning outcomes is low and has not reached the Indonesian KKM is 70 . Teachers use less variation in the process of learning Indonesian, in other words teachers tend to use conventional methods in which teachercentered learning activities, so that students are less active in the learning process where students are less able to express their opinions.

One of the fundamental things that teachers need to understand is how to understand the position of the learning model as one of the components for the success of learning activities. Teachers need to determine the appropriate model of learning so that the material can be easily understood learning students, teachers are obliged to implement improvements in learning.

The SQ4R model (survey, question, read, reflect, recite, and review) is one of the techniques of reading to understand the content of the reading that uses the steps systematically in its implementation. In using this model of course, a reader needs to determine in advance the purpose of reading. In addition, readers also need to determine the focus information they need. Where in this model, students are directed to scrutinize, create questions, read texts, review, and provide

The learning process is a very important element in the process of education in schools. A person's view of learning affects his or her learning-related actions and everyone has a different view of learning. By learning human beings will be able to change itself towards the better in terms of knowledge, skills, and attitude. Psychologically, learning is a process of change that changes behavior as a result of interaction with the environment in meeting their needs, the changes will be evident throughout aspects of behavior.

[1] says that learning is a process of behavior examples in the actual context. With this learning model is expected to learn Indonesian student learning can be increased. Change to achieve a wide range of knowledge, skills and attitudes. Learning is a process of interaction between stimulus and response. Learning is considered as a process of behavior change as a result of the experience and practice Learning is a process of behavior change due to experience and practice. The objective of the study is the change in behavior, both concerning the knowledge, skills, attitudes [2]. According to [3]. Learning is defined as a persisting change in human performance or performance potential, learning comes about as a consequence of, the learner's experience and interaction with the world. Based on the above quote, learning is defined as the last change in human performance or potential performance, learning emerged as a consequence of the student experience and interaction with the environment.

Learning is a process attempts someone who aims to obtain a change in behavior or overall appearance both concerning the knowledge, skills, attitudes with a series of learning activities for example by reading, watching, listening, etc. It can be concluded that learning can not be separated from human life. Where learning is a process of interaction with the environment. Learning can also be interpreted as the individual events, the events of the occurrence of a change in behavior as a result of the experience. Learning would be better if the subject learning experience or do it yourself through a variety of events and activities they do.

It's basically what the results obtained from an activity, while learning is a process that resulted in a change in individuals, the changes in behavior, both aspects of the knowledge, 
skills and attitude aspects. The learning result is a term used to indicate the level of success achieved by a person after certain business. In this case the learning outcomes achieved by students in a particular field of study after participating in the learning process. In the process of obtaining a good result it is necessary to learn appropriate learning methods means that in accordance with the conditions and circumstances of everyday life are contextual, so what is the result of learning can be met with a number of measurements of learning outcomes that meet the standards.

According to [4] learning is generally interpreted as a change in individuals that occur through experience, and not because of the growth or development of the body or characteristics of a person from birth". Meanwhile, according to [5] learning is a business or activity that aims to make changes within a person include changes in behavior, attitudes, habits, science, skills, and so on. Meanwhile, according to [6] learning is a process of business undertaken by a person to gain a new change of behavior as a whole, as a result of his own experience in interaction with the environment. From some of the expert opinions above can be understood that the changes include the goals that want to be gen Education is an effort of every nation and state to pass on knowledge from generation to generation. The education is also expected to create high quality and competitive learners to face the competition in the globalization era today. Improving the quality of human resources is one of the emphasis of educational goals. The success of the national education system is strongly influenced by the teaching process that the teacher provides. Therefore, teachers as educators should be able to create an atmosphere of learning that can help improve the quality of education peoses itself.

Indonesian as a communication tool of Indonesian society that has a role to lead and deliver knowledge to various circles and level of education. All levels of education in delivery, of course using the Indonesian language as the introduction. Therefore, the Indonesian language clearly has an important role as a material science and technology in its dissemination to the world of education.

In accordance with the position of Bahasa Indonesia as the national language and the language of the country. So, the function of Indonesian language and literature subjects are: (1) means of fostering unity and unity of the nation (2) means of improving knowledge and skills of Indonesian language in order to preserve and develop culture (3) means of increasing knowledge and skills of Indonesian language to reach and develop science Knowledge, skills and art (4) means of disseminating the use of good Indonesian bebah for the purposes of various problems, and (5) means of developing reasoning.

The scope of Indonesian language and literature subjects covers language mastery, ability to understand, appreciate literature, and the ability to use the Indonesian. Indonesian learning is directed to improve students' ability to communicate in good and correct Indonesian, either orally or in writing. In learning Indonesian in primary school there are four aspects of language skills that include listening, speaking, reading and writing skills. The four aspects of language skills are related to one another.

Based on the results of observations and interviews of researchers to teachers of primary school in Medan is known that the value of student learning outcomes is low and has not reached the Indonesian KKM is 70 . Teachers use less variation in the process of learning Indonesian, in other words teachers tend to use conventional methods in which teachercentered learning activities, so that students are less active in the learning process where students are less able to express their opinions.

One of the fundamental things that teachers need to understand is how to understand the position of the learning model as one of the components for the success of learning activities. 
Teachers need to determine the appropriate model of learning so that the material can be easily understood learning students, teachers are obliged to implement improvements in learning.

The SQ4R model (survey, question, read, reflect, recite, and review) is one of the techniques of reading to understand the content of the reading that uses the steps systematically in its implementation. In using this model of course, a reader needs to determine in advance the purpose of reading. In addition, readers also need to determine the focus information they need. Where in this model, students are directed to scrutinize, create questions, read texts, review, and provide examples in the actual context. With this learning model is expected to learn Indonesian student learning can be increased. The learning process is a very important element in the process of education in schools. A person's view of learning affects his or her learning-related actions and everyone has a different view of learning. By learning human beings will be able to change itself towards the better in terms of knowledge, skills, and attitude. Psychologically, learning is a process of change that changes behavior as a result of interaction with the environment in meeting their needs, the changes will be evident throughout aspects of behavior.

[1] says that learning is a process of behavior change to achieve a wide range of knowledge, skills and attitudes. Learning is a process of interaction between stimulus and response. Learning is considered as a process of behavior change as a result of the experience and practice learning is a process of behavior change due to experience and practice. The objective of the study is the change in behavior, both concerning the knowledge, skills, attitudes [2]. According to[3].

Learning is defined as a persisting change in human performance or performance potential, learning comes about as a consequence of, the learner's experience and interaction with the world. Based on the above quote, learning is defined as the last change in human performance or potential performance, learning emerged as a consequence of the student experience and interaction with the environment.

Learning is a process attempts someone who aims to obtain a change in behavior or overall appearance both concerning the knowledge, skills, attitudes with a series of learning activities for example by reading, watching, listening, etc. It can be concluded that learning can not be separated from human life. Where learning is a process of interaction with the environment. Learning can also be interpreted as the individual events, the events of the occurrence of a change in behavior as a result of the experience. Learning would be better if the subject learning experience or do it yourself through a variety of events and activities they do.

It's basically what the results obtained from an activity, while learning is a process that resulted in a change in individuals, the changes in behavior, both aspects of the knowledge, skills and attitude aspects. The learning result is a term used to indicate the level of success achieved by a person after certain business. In this case the learning outcomes achieved by students in a particular field of study after participating in the learning process. In the process of obtaining a good result it is necessary to learn appropriate learning methods means that in accordance with the conditions and circumstances of everyday life are contextual, so what is the result of learning can be met with a number of measurements of learning outcomes that meet the standards.

According to [4] learning is generally interpreted as a change in individuals that occur through experience, and not because of the growth or development of the body or characteristics of a person from birth". Meanwhile, according to [5] learning is a business or activity that aims to make changes within a person include changes in behavior, attitudes, habits, science, skills, and so on. Meanwhile, according to[6], learning is a process of business 
undertaken by a person to gain a new change of behavior as a whole, as a result of his own experience in interaction with the environment. From some of the expert opinions above can be understood that the changes include the goals that want to be generated from the learning process as a result of business or activities in the form of experience in interaction with the environment. This is reinforced by the opinion of [7] learning is a change of behavior or appearance, with a series of activities. For example, by reading, observing, listening, imitating, and so on. Based on the opinions of the experts above, it can be defined that learning is an activity aimed at generating behavioral changes based on individual experience in interaction with the environment, which involves cognitive, affective, and psychomotor aspects. Erated from the learning process as a result of business or activities in the form of experience in interaction with the environment.

This is reinforced by the opinion of [7] slearning is a change of behavior or appearance, with a series of activities. For example, by reading, observing, listening, imitating, and so on. Based on the opinions of the experts above, it can be defined that learning is an activity aimed at generating behavioral changes based on individual experience in interaction with the environment, which involves cognitive, affective, and psychomotor aspects.

Education is an effort of every nation and state to pass on knowledge from generation to generation. The education is also expected to create high quality and competitive learners to face the competition in the globalization era today. Improving the quality of human resources is one of the emphasis of educational goals. The success of the national education system is strongly influenced by the teaching process that the teacher provides. Therefore, teachers as educators should be able to create an atmosphere of learning that can help improve the quality of education peoses itself. Indonesian as a communication tool of Indonesian society that has a role to lead and deliver knowledge to various circles and level of education. All levels of education in delivery, of course using the Indonesian language as the introduction. Therefore, the Indonesian language clearly has an important role as a material science and technology in its dissemination to the world of education.

In accordance with the position of Bahasa Indonesia as the national language and the language of the country. So, the function of Indonesian language and literature subjects are: (1) means of fostering unity and unity of the nation (2) means of improving knowledge and skills of Indonesian language in order to preserve and develop culture (3) means of increasing knowledge and skills of Indonesian language to reach and develop science Knowledge, skills and art (4) means of disseminating the use of good Indonesian bebah for the purposes of various problems, and (5) means of developing reasoning.

The scope of Indonesian language and literature subjects covers language mastery, ability to understand, appreciate literature, and the ability to use the Indonesian. Indonesian learning is directed to improve students' ability to communicate in good and correct Indonesian, either orally or in writing. In learning Indonesian in primary school there are four aspects of language skills that include listening, speaking, reading and writing skills. The four aspects of language skills are related to one another. Based on the results of observations and interviews of researchers to teachers of primary school in Medan is known that the value of student learning outcomes is low and has not reached the Indonesian KKM is 70. Teachers use less variation in the process of learning Indonesian, in other words teachers tend to use conventional methods in which teacher-centered learning activities, so that students are less active in the learning process where students are less able to express their opinions.

One of the fundamental things that teachers need to understand is how to understand the position of the learning model as one of the components for the success of learning activities. 
Teachers need to determine the appropriate model of learning so that the material can be easily understood learning students, teachers are obliged to implement improvements in learning.

The SQ4R model (survey, question, read, reflect, recite, and review) is one of the techniques of reading to understand the content of the reading that uses the steps systematically in its implementation. In using this model of course, a reader needs to determine in advance the purpose of reading. In addition, readers also need to determine the focus information they need. Where in this model, students are directed to scrutinize, create questions, read texts, review, and provide examples in the actual context. With this learning model is expected to learn Indonesian student learning can be increased.

The learning process is a very important element in the process of education in schools. A person's view of learning affects his or her learning-related actions and everyone has a different view of learning. By learning human beings will be able to change itself towards the better in terms of knowledge, skills, and attitude. Psychologically, learning is a process of change that changes behavior as a result of interaction with the environment in meeting their needs, the changes will be evident throughout aspects of behavior.

[1] says that learning is a process of behavior change to achieve a wide range of knowledge, skills and attitudes. Learning is a process of interaction between stimulus and response. Learning is considered as a process of behavior change as a result of the experience and practice learning is a process of behavior change due to experience and practice. The objective of the study is the change in behavior, both concerning the knowledge, skills, attitudes [2]. According to[3] .Learning is defined as a persisting change in human performance or performance potential, learning comes about as a consequence of, the learner's experience and interaction with the world. Based on the above quote, learning is defined as the last change in human performance or potential performance, learning emerged as a consequence of the student experience and interaction with the environment.

Learning is a process attempts someone who aims to obtain a change in behavior or overall appearance both concerning the knowledge, skills, attitudes with a series of learning activities for example by reading, watching, listening, etc. It can be concluded that learning can not be separated from human life. Where learning is a process of interaction with the environment. Learning can also be interpreted as the individual events, the events of the occurrence of a change in behavior as a result of the experience. Learning would be better if the subject learning experience or do it yourself through a variety of events and activities they do.

It's basically what the results obtained from an activity, while learning is a process that resulted in a change in individuals, the changes in behavior, both aspects of the knowledge, skills and attitude aspects. The learning result is a term used to indicate the level of success achieved by a person after certain business. In this case the learning outcomes achieved by students in a particular field of study after participating in the learning process. In the process of obtaining a good result it is necessary to learn appropriate learning methods means that in accordance with the conditions and circumstances of everyday life are contextual, so what is the result of learning can be met with a number of measurements of learning outcomes that meet the standards.

According to [4] learning is generally interpreted as a change in individuals that occur through experience, and not because of the growth or development of the body or characteristics of a person from birth". Meanwhile, according to [5] learning is a business or activity that aims to make changes within a person include changes in behavior, attitudes, habits, science, skills, and so on. Meanwhile, according to[6], learning is a process of business undertaken by a person to gain a new change of behavior as a whole, as a result of his own 
experience in interaction with the environment. From some of the expert opinions above can be understood that the changes include [1] the goals that want to be generated from the learning process as a result of business or activities in the form of experience in interaction with the environment.

This is reinforced by the opinion of [7] learning is a change of behavior or appearance, with a series of activities. For example, by reading, observing, listening, imitating, and so on. Based on the opinions of the experts above, it can be defined that learning is an activity aimed at generating behavioral changes based on individual experience in interaction with the environment, which involves cognitive, affective, and psychomotor aspects.

\section{Methodology}

\subsection{Learning Outcomes}

In every learning process, learning outcomes are benchmarks in determining the success rate of one's learning activity based on the learning experience. Both learning outcomes are based on the cognitive, affective, and psychomotor domains. says that learning outcomes are the results achieved by students who have followed the process of learning.

Gagne outlines the behavioral changes that are the result of learning can be: a) the information verbally, namely the mastery of information in verbal form, either orally or in writing, b) intellectual faculties, namely individual skills in interacting with its environment by using symbols, c) strategies cognitive, an individual's ability to perform the overall management of activities. In the context of the learning process is the ability to use the strategy cognitive memories and ways of thinking that occurs effective activity, d) attitude, the learning outcomes in the form of an individual's ability to choose the kind of action to be carried out, e) is the result of learning motor skills in the form of skills be controlled by muscle and physical. Based on the opinion of the learning outcomes are concrete actions consist of demonstration of knowledge, skills and values [8].

It's basically what the results obtained from an activity, while learning is a process that resulted in a change in individuals, the changes in behavior, both aspects of the knowledge, skills and attitude aspects. The learning result is a term used to indicate the level of success achieved by a person after certain business. In this case the learning outcomes achieved by students in a particular field of study after participating in the learning process. In the process of obtaining a good result it is necessary to learn appropriate learning methods means that in accordance with the conditions and circumstances of everyday life are contextual, so what is the result of learning can be met with a number of measurements of learning outcomes that meet the standards.

Furthermore, according to [9] changes as a result of the learning process can be shown in various forms, such as skills, habits, attitudes, acceptance, or appreciation. Such changes may include his condition, his knowledge and his actions ". This is in line with Hamalik's opinion the results of learning appear in each change aspects as follows: "a) knowledge, b) understanding, c) habits, d) skills, e) appreciation, f) emotional, g) Social relations, h) physical, i) manners, j) attitude [10].

Learning outcomes are the abilities students have after receiving the learning experience. To evaluate the expected student learning outcomes, it is necessary to have operational objectives that are objectives of behavior that can be done and measured. According to [11] that: "Learning outcomes are changes in behavior as a whole is not just one aspect of human 
potential alone, meaning learning outcomes are not fragmentary or separate but comprehensive."

Most theorists of " cognitive knowledge" as the informasion that people $i$ the know about the factors associated with homework and learning strategies, and "cognitive set" to a variaty of administrative actions, such as attention, reviewing, planning, and identification of errors at the point and the impact of cognitive activities, or their differences, metacognitives beliefs prominent role in guilding behavior [12].

Meanwhile, according to [13] said that: learning outcomes is a change in behavior as a result of learning in the sense that should cover the field of cognitive, affective, and paikomotoris. Therefore, in the assessment of learning outcomes, the instructional role that contains the formulation of the desired abilities and behaviors controlled by students becomes an important element as the basis and reference of assessment.

Based on the opinion of the experts above can be concluded that the results of learning is a behavioral change that includes aspects of cognitive, affective, and psychomotor based on the assessment conducted in the process of learning activities. Where the changes can be applied in everyday life.

Factors Affecting Learning Outcomes

Low learning outcomes are a constraint in every learning process. Therefore, teachers as educators should find a solution of any problems that hinder the success of the learning process such as low student learning outcomes. Therefore, to achieve learning outcomes in accordance with the expected it is necessary to note several factors that influence the learning outcomes. In this case [14] classify factors that influence learning outcomes directly or indirectly into four groups, namely: (1) learner factors that include basic capacity, special talent, motivation, interest, maturity and readiness, Attitudes and habits. (2) factors of good facilities and infrastructures related to the quality, completeness, and usage. (3) environmental factors, whether physical, social, and culture where the learning activities implemented.

Furthermore [6] argues that: "Factors that affect learning outcomes of many types, but can be classified into two groups only, namely internal and external factors. Internal factors are factors that exist within the individual who is learning, while external factors are factors that exist outside the individual. In addition to learning models, other factors that affect the success of a learning process is the students themselves. Students have characteristics that can affect student achievement include: gender and learning style [15].

[16] explains that the factors that influence learning outcomes are as follows: (a) internal factors, ie factors that originate within the self itself, which includes two physiological aspects of a physical nature and psychological aspects that are spiritual In the organism. (b) the external factor of the student, the factor that comes from outside the student's self, which consists of two kinds of social environment factors (such as teachers, administrative staff and classmates) and social environment factors (such as school buildings and their location, Student's family residence, learning tools, weather conditions, and study time used by students). (c) learning approach factor that is kind of student learning effort which include strategy and method used by student to do activity studying learning materials.

Based on the opinion of the experts above can be concluded that the results of student learning is influenced by factors of self-discipline students in the form of interest, motivation, self concept, and attitude in learning. But besides that, there are factors that influence the outcomes of learning from outside the students self is the school environment, family environment, and community environment.

Models are the means used by teachers in carrying out teaching and learning activities in the classroom as an effort to achieve to achieve the learning objectives that have been set. In 
learning activities, models are needed by teachers and use varies according to the goals to be achieved. A teacher will not achieve and complete the learning objectives well if not mastered and use methods that are appropriate to the learning objectives.

According [16] that: model is a strategy or a way that contains standard procedures for carrying out the presentation of materials to students. This is in line with the opinion of [17] that "'model is a means used to achieve predetermined goals". Meanwhile, according to [18] that, "the model is the whole set of presentation of teaching materials that cover all aspects before and after the learning process conducted by teachers and all related facilities used directly or indirectly in the teaching and learning process".

Based on the opinion of the experts above can be concluded that the model is a way or teaching strategies undertaken by the teacher in the ongoing learning process to achieve learning objectives and tailored to the conditions, situations and materials to be taught.

\subsection{Model Survey, Question, Read,Reflect, Recite, Review (SQ4R)}

In improving student learning outcomes, there are many things teachers can do. One way is to apply the appropriate learning model. So as to achieve the objectives of each learning activities undertaken. One such model is the SQ4R model (Survey, Question, Read, Reflect, Recite, Review). Where [15] states that the SQ4R learning model produces better learning outcomes than SQ3R and Direct learning.

According to [19] One of the most popular memory improvement techniques, is SQ4R This method name is made by six initial related to learning and memory organized as a prereading, question, read / think, memorize, and review saying SQ4R. According to [9] SQ4R is the development of SQ3R by adding the reflect element, which is the activity of providing examples of reading material and envisioning the relevant actual context.

According to [20] SQ4R is one of the learning models ynag is the solution of the problem of low comprehension ability of reading. This model is a development of the SQ3R method by adding the Reflect element, ie the teacher's activity provides an open-ended problem related to the actual context relevant to daily life. Then students will slaing discuss with friends of his group to find solutions of the problems based on the knowledge they have gained in the read stage. The existence of problems that are open-ended, can cause critical thinking of students and teachers to know the extent of knowledge that has been owned by students.

Furthermore, according to Uno (2012: 115) SQ4R is one part of elaboration strategy that serves to form students' habits of concentrating in reading, practicing fast reading skills, practicing forecasting power with regard to reading content and developing critical and cooperative reading skills. More details [21] explains that the intent of the Survey, Question, Read, Reflect, recite, study model is as follows: a). Surveys by looking at text reading and note-marking keywords; b). Question by making a question (why-how, from which) about reading material (teaching material material); c). Read by reading the text and looking for the answer; d). Reflect ie activity provides examples of reading material and envisages the relevant actual context; E). Review by thorough reviewing; f). Recite considering the given answer note-sharing together.

[22] One of the most popular techniques to improve memory, pre- reading, question, read, think, say, and review the method of preservation is so famous conclusion. Learning is one of the main sources of environmental compability. Student efficacy, then other of your abilities, your knowledge and less compared to other according to their standards and capabilities to deal with learning problems. Is seen in terms of ability and talent students who are learning the same level, academic performance when you try and learn to try different 
show. Based on the opinion of the experts above can be defined that the model SQ4R is a model of learning in which there are several steps such as surveys, question, read, reflect, recite, reviews that are considered able to assist teachers in knowing how far the knowledge has been owned students.

In the application of the SQ4R model there are several benefits that are, according to [4] the general benefit of this model, which helps learners to take the position that the read source will be read as necessary or not, equip learners with a systematic approach To the types of reading, facilitate learners in understanding the contents of readings that are read. Based on the opinion of the experts above can be concluded that the benefits of the SQ4R model is to help students in improving their skills both in terms of knowledge, concentration of critical thinking, and improve learning outcomes.

In this study leads to a strategy that builds a general picture of the material being taught, creates questions and finds answers to questions independently, and is able to provide relevant examples in actuality. The steps of implementation of learning through SQ4R strategy in class $\mathrm{V}$ students in this study according to [23] include: a) Teachers open lessons and inform learning goals. b) teachers provide text reading that will be read by students. The text used has different headings in each of its meetings. c) the teacher opens the lesson with apersepsi in accordance with the purpose of learning. d) Students form groups of 4-5 students. The group formed will be assigned to discuss the given worksheet. e) After each group receives the text, the teacher gives the task of reading the survey, including the title, the length of the text, the many paragraphs, and possible terms. f) each group member makes a question of reading. g) group representatives to read each paragraph in turn. while other group members listen carefully while seeking answers to the questions that have been made. $h$ ) group members write down answers to these questions and then take turns reading them in front of the group. Group members who did not take turns read the answers to the task of defining the correctness of the reflected answers: a) students write down the content of the story and retell it in their own language (recite), b) the group rereading the reading (revieu) To complete new tasks together, ie by making conclusions or digest. c) Student with teacher concludes learning that has been done, d) teacher give test to student.

Each model of learning can have several deficiencies and advantages. Included in the SQ4R learning model (Survey, Question, Read, Reflect, Recite, Review). In his book [21] describes several advantages and disadvantages of the SQ4R learning model, including as follows: The advantages of SQ4R are as follows: a) with a survey stage at the beginning of the lesson, it arouses students' curiosity about the material to be learned so as to increase student motivation in learning. B) students are given the opportunity to ask their own questions and try to find answers from the question itself by doing the reading activity. Thus, it can encourage students to think critically, be active in learning and meaningful learning. c) the material students learn is attached to longer periods of time. The weakness of SQ4R, is as follows: a) this strategy can not be applied to all subjects of physics and because the material of physics is not always easy to understand by reading only, but also the need for practicum, b) the teacher will have difficulty in preparing the reading book for each student if not all students have a reading book.

Table 2. Normality Test

\begin{tabular}{llllllll}
\hline No & Data Of Class & Average & $\begin{array}{l}\text { Table 2. Normality Test } \\
\text { Seviation }\end{array}$ & L0 & $\begin{array}{l}\text { L table } \\
(\mathrm{Lt})\end{array}$ & Criteria & Information \\
\hline 1 & $\begin{array}{l}\text { Normality Test of } \\
\text { Pre-Test of } \\
\text { Experiment Class }\end{array}$ & 43,3 & 8,23 & 0,156 & 0,161 & $\mathrm{~L}_{0}<\mathrm{L}_{\mathrm{t}}$ & NORMAL \\
& & & & & & \\
\hline
\end{tabular}




\begin{tabular}{llcccccc}
\hline 2 & $\begin{array}{l}\text { Normality Test of } \\
\text { Post Test of } \\
\text { Experiment Class }\end{array}$ & 74,2 & 13,52 & 0,157 & 0,161 & $\mathrm{~L}_{0}<\mathrm{L}_{\mathrm{t}}$ & NORMAL \\
\hline $\begin{array}{l}\text { Normality Test of } \\
\text { Pre-Test of Control } \\
\text { Class }\end{array}$ & 55,16 & 10,46 & 0,134 & 0,161 & $\mathrm{~L}_{0}<\mathrm{L}_{\mathrm{t}}$ & NORMAL \\
4 & $\begin{array}{l}\text { Normality Test of } \\
\text { Post Test of Control } \\
\text { Class }\end{array}$ & 63,66 & 10,9 & 0,149 & 0,161 & $\mathrm{~L}_{0}<\mathrm{L}_{\mathrm{t}}$ & NORMAL \\
\hline
\end{tabular}

The type of research used in this study is quasi experimental research using nonequivalent control group design. The none-quivalent control group design study was a study comparing pretest and posttest values. The population in this study is all students of grade V SDN in Medan. The research consists of 2 classes Samples totaling 60 students.

The procedure of this research is done by three stages: a) conducting pretest that is conducting test to know the student's early ability about the subject matter to be delivered either in the experimental class or control class with the same test question. B) implementing teaching treatment that is by using elaboration approach (SQ4R method) in the experimental class and provide teaching treatment using expository approach in the control class c) holding post test that is conducting test to know the student's active ability about the learning material which has been delivered with the same problem after being given the teaching treatment each (See Table 1.).

\section{Result and Discussion}

Description of Research Data Result This research was conducted in Grade V of elementary school in Medan in. This research involves two classes which are given different learning approach, that is experiment class by using SQ4R model and control class using expository approach. This study uses multiple choice test instruments that amounted to 20 questions. Before the test instrument is given to the students of class $\mathrm{V}$ elementary school in Medan, then the first instrument is tested the level of validity. Before the two classes were given different teaching treatments, the two classes were first given a pre-test that aims to determine the initial learning ability of each class. Whereas post test is given to know student learning outcomes after learning with different treatment in both sample groups.

From mean of pre test of 43,3 in experiment class, it is necessary to follow up by doing treatment that is using SQ4R model in experiment class, after conducted test treatment with pre test to post test increased to 74,2. And the value of each student increases from pre test to post test. From the average pre test of 55.2 in the control class, it is necessary to follow up by conducting the treatment that is using the lecture method in the control class, after the treatment is then tested with post test where the average value increased to 63.7.

Normality Test is a test to control whether the data obtained has a normal distribution can be used in statistics. The purpose of the Normality test is to find out whether the distribution is nornal. Testing of Normality of Data Pre test in control and experimental class is done by Liliefors test, with significance level $(\alpha=0,05)$, with test criterion Normality is Lcount $<$ Ltable then sample is Normal distributed

Based on the table beside it can be concluded that the data of the 2 research classes is normally distributed. After the research data collected, and the data have been tested first with 
the normality test and the result is normal distribution then the next test Homogeneity with criteria Fcount $<$ Ftable, it can be stated Homogeneous (See Table 2).

Table 2. Homogeneous Test

\begin{tabular}{cccccc}
\hline & Kelas & Kelas & tabel & thitung & Kriteria \\
\hline $\mathrm{N}$ (amount) & 30 & 30 & 2,076 & 3,324 & $\mathrm{~T}_{\text {count }}>$ \\
$\mathrm{S}$ & 13,52 & 10,9 & & & table \\
$\mathrm{S}^{2}$ & 182,8 & 118,8 & & & \\
\hline
\end{tabular}

Based on the above table, it can be concluded that the learning result data of Indonesian language of students class V A and V B with SQ4R model and expository method are stated to have the same or homogeneous variance.

\subsection{Hypothesis Testing}

From the above discussion has been tested Normality and the results are normal. Homogeneity and homogeneous results have also been conducted (See Table 3).

\begin{tabular}{cccccc}
\hline No & Data of Class & Fcount & Ftable & Criteria & Information \\
\hline 1 & $\begin{array}{l}\text { Homogeneous Test } \\
\text { of Post Test of }\end{array}$ & 1,61 & 1,87 & $\begin{array}{l}\text { Fcount }< \\
\text { Ftable }\end{array}$ & Homogeneous \\
2 & $\begin{array}{l}\text { Control Class } \\
\text { Homogeneous Test } \\
\text { of Post Test of } \\
\text { Control Class }\end{array}$ & 1,54 & 1,87 & $\begin{array}{l}\text { Fcount }< \\
\text { Ftable }\end{array}$ & Homogeneous \\
\hline
\end{tabular}

From the table above can be concluded that tcount $>$ ttable where 3,324>2.076 by proving that Ha accepted, there is a positive influence between SQ4R model on the learning outcomes Indonesian language of students.

\subsection{Discussion}

The research conducted at SDN in Medan aims to determine the effect of SQ4R model on the learning outcomes of Indonesian language. This research is classified as an experimental research involving two classes with different treatment. Class V A as experiment class and class V B as control class. Students' learning outcomes are based on individual absorption and classical absorption. Absorption capacity referred to in this study is seen from the final test score after the students held the learning process using SQ4R model. Before doing the research, the researcher first tested the test in the form of validity test, test reliability, differentiator test and test difficulty level to 20 students who are considered to have the same criteria as the research sample.

After testing the research instrument consisting of 50 items where 20 items were declared valid and used as a tool of data collecting about learning result of Indonesian language with material of folklore. To know the students' initial ability, the researcher performs the Pre-test in the experimental class and control class. Where the number of test questions as many as 20 questions and the same type of problem, obtained the results of experimental class with average score of 43.3 and obtained the results of control class with an average score of 55.2. Can be seen the results of the ability of the initial test low students. Furthermore, the two classes were given different treatment. The experimental class applied the SQ4R model and the control class applied the expository approach particularly with the use of lecture methods. 
After that both classes are given a post test with the same problem as in the matter of pre-test, but the sequence of question numbers are randomized. In the experimental class obtained an average post-test capability of 74.2 and in the class of kontol obtained average post test ability is 63.7. It can be seen that a higher pre-test and post test score is an experimental class with SQ4R model. And with SQ4R model students are able to achieve an average value above the KKM. So, this research can be said to be successful.

This research is in line with research conducted by Putu Indah Widayadnyani Rahayu. Where the analysis results show thit $=4.21$ while ttab at $5 \%$ significance level with $\mathrm{dk}=73$ of 2,000 , so thit $>$ ttab. This analysis shows that Ha is accepted and H0 is rejected. In addition, other related studies also show the same where the research conducted at SMP Empu Tantular Semarang shows the results of research that has been obtained obtained the average post test class experimental rate is 76.07 and the average control class that is 70.61 . The result of hypothesis test ( $\mathrm{t}$ test and simple regression test) post test value got significance value $=0,00$ $<$ significance level $=0,05$ which mean there is difference of result of experiment class study history with control class, whereas simple regression test significance value $=0,037$ with The level of significance $=0.05$ because the level of significance $<$ level of significance it can be concluded Ha accepted which means there is influence of learning SQ4R on student learning outcomes. Coefficient of determination $=0.689$. This means that $68.9 \%$ of student learning outcomes are influenced by SQ4R learning and the remaining $31.1 \%$ is influenced by other factors. The percentage of completeness of experimental class learning result is $89.47 \% \geq$ $75 \%$, while the percentage of mastery of classical learning achievement of control class reaches $56.75 \%<75 \%$. So, it can be concluded that Learning by using SQ4R model more effective.

\section{Conclusion}

Based on the results of the research it can be concluded as follows:

a. The results showed that the learning outcomes of Indonesian language students elementary school after applied SQ4R model increased compared with the result of learning Indonesian students using expository approach. Thus it can be seen that there are improvements that occur to the learning result of Indonesian language using SQ4R model. It can be seen from the average of test result using SQ4R model that is 74,2 . While the test results with expository approach method of lecturing is 63.7.

b. There is a positive and significant influence between the use of SQ4R model on the learning outcomes of Indonesian language of students in elementary school. It can be seen from the results of the hypothesis test calculation obtained tcount $>$ ttable is $3.324>2.076$ at a significant level $\alpha=0.05$.

\section{References}

[1] R. Thorndike, Measurement and Education in Psychology and Education. Fifth Edition. New York: Macmillan Publishing, 1997.

[2] A. Sabri, Srategi Belajar Mengajar \& Micro Teaching. Jakarta: Ciptat Press, 2010.

[3] J. W. Reisser, Robert E. and Dempsey, Trend and Issues in Instructional Design and Technology. New Jersey: Pearson Education Inc., 2007.

[4] Trianto, Model Pembelajaran Terpadu. Jakarta: Bumi AKsara, 2010.

[5] M. Khairani, Psikologi Belajar. Yogyakarta: Aswaja Presindo, 2013.

[6] Slameto, Belajar dan Faktor-Faktor Yang Mempengaruhinya. Jakarta: Rineka Cipta, 2010. 
[7] A. M. Sardiman, Interaksi \& motivasi belajar mengajar. Rajagrafindo Persada (Rajawali Pers), 2004.

[8] R. M. Gagné, "The Conditions of Learning (Holt, Rinehart and Winston, New York)," Google Sch., 1985.

[9] dkk. Ngalimun, Strategi dan Model Pembelajaran. Yogyakarta: Aswaja Pressindo, 2016.

[10] O. Hamalik, Proses belajar mengajar. Bumi Aksara, 2004.

[11] S. Agus, "Cooperative Learning dan Aplikasi PAIKEM." Yogyakarta: Pustaka Pelajar, 2010.

[12] R. Brown, "Social identity theory: Past achievements, current problems and future challenges," Eur. J. Soc. Psychol., vol. 30, no. 6, pp. 745-778, 2000.

[13] N. Sudjana, "Dasar-dasar Proses Belajar Mengajar, Bandung: Sinar Baru," Algesindo Offset, 2006.

[14] Z. Aqib, "Penelitian tindakan kelas." Bandung: Yrama Widya, 2006.

[15] S. Wulandari, B. Budiyono, and G. Iswahyudi, "Eksperimentasi Model Pembelajaran Survey, Question, Read, Recite, Review (Sq3r) Dan Survey, Question, Read, Reflect, Recite, Review (Sq4r) Ditinjau Dari Jenis Kelamin Dan Gaya Belajar,” J. Pembelajaran Mat., vol. 4, no. 1, 2016.

[16] S. Muhibbin, "Psikologi pendidikan dengan pendekatan baru," Bandung PT Remaja Rosdakarya, 2010.

[17] E. Siregar, . Teori Belajar dan Pembelajaran. Jakarta: Ghalia Indonesia, 2010.

[18] Istarani., 58 Model Pembelajaran Inovatif. Medan: Media Persada, 2011.

[19] B. A. Higgins, "An Analysis of the Effects of Integrated Instruction of Metacognitive and Study Skills upon the Self-Efficacy and Achievement of Male and Female Students.," 2000.

[20] P. E. Doolittle, D. Hicks, C. F. Triplett, W. D. Nichols, and C. A. Young, "Reciprocal teaching for reading comprehension in higher education: A strategy for fostering the deeper understanding of texts," Int. J. Teach. Learn. High. Educ., vol. 17, no. 2, pp. 106-118, 2006.

[21] A. Shoimin, "model pembelajaran inovatif dalam kurikulum 2013." Yogyakarta: Ar-Ruzz Media, 2016.

[22] A. M. Kosnin, "Self-regulated learning and academic achievement in Malaysian undergraduates.," Int. Educ. J., vol. 8, no. 1, pp. 221-228, 2007.

[23] S. I. Runiatun and M. I. S. Matsuri, "Penggunaan Strategi Sq4r (Survey, Question, Read, Reflect, Recite, Review) Untuk Meningkatkan Keterampilan Membaca Pemahaman," $J$. Didakt. Dwija Indria, vol. 4, no. 11, 2016. 